\title{
FIELD TRIALS WITH INSECTICIDES FOR CONTROL OF SUBTERRANEAN GRASS CATERPILLAR (WISEANA Spp.)
}

\author{
G. N. ARThur and G. R. CASSEls \\ Geigy Agricultural Chemicals, Palmerston North
}

Summary

In a series of trials, diazinon wettable powder caused a rapid kill of subterranean grass caterpillar (Wiseana spp.). Affected larvae were found on the soil surface the morning following treatment. Subsequent observations showed that application of diazinon wettable powder and granular formulations led to a pasture response on infested sites. Soil mulations led to a pasture response on ined these treatments cause a reduction in larval population.

\section{INTRODUCTION}

THE subterranean grass caterpillar (Wiseana spp.) is recognized THE subterranean grass caterpillar (Wiseana spp.) is recognized annisally by the genus has been estimated at $f 6,000,000$ (Entomology annialis by 1961). Historically wet-mix and dry-mix DDT superphosDivision, 196 measures but phate have been accepted as the materials have instigated the appraisal of materials and formulations which will not cause unacceptable residues in milk or animal tissue.

This paper principally reports on trials carried out with diazinon but data are also included on DDT granules, trichlorphon s.p. and a wettable powder and granular formulation of a recent organophosphate insecticide, GS.13005. When trials were commenced, there phate insecticide, GS.13005. were no data to indicate whether diazinon materials was to ascertain the ability to provide a "knockdown" of larvae. The method of assessment was to count larvae found on the ground surface following treatment. Further observations were made to establish whether insecticide treatments led to visible pasture response compared with untreated areas. Soil counts were pasture response to residual population at various time intervals following treatment. Current trials are expected to provide data on pasture yields for various treatments.

\section{EXPERIMENTAL}

The three trials considered in this paper were all located in Canterbury on sites heavily infested with larvae of the subterranean grass caterpillar. The trials comprised three replicates with plot grass caterpillar. The trials comprised $1 / 160$ th acre. The granular formulations were spread by hand and the powder formulations were mixed with water and applied as sprays. All application rates are shown in terms of active ingredient per acre. Treatment dates were as follows: Trial 1, April 1964; Trial 2, July 1964; Trial 3, March 1965. 
INITIAL KNOCKDOWN OF LARVAE

\section{Trial 1}

Table 1 shows mean counts per plot of affected larvae on the soil surface within 36 hours of treatment with diazinon wettable powder and granules. The majority of larvae were found on the morning following treatment. Larvae at time of treatment were 1 to $1.5 \mathrm{in}$. long.

TABLE 1: MEAN COUNTS OF AFFECTED LARVAE PER PLOT (TRIAL 1)

\begin{tabular}{|c|c|c|c|c|c|c|c|c|c|}
\hline \multirow[b]{2}{*}{ Treatment } & & & & & & & \multicolumn{3}{|c|}{ Rate (lb) } \\
\hline & & & & & & & 0.5 & 1.0 & 2.0 \\
\hline $\begin{array}{l}\text { Diazinon w.p. } \\
\text { Diazinon g. }\end{array}$ & $\begin{array}{l}\ldots \ldots . . \\
\ldots \ldots . .\end{array}$ & $\ldots$ & $\ldots \ldots$ & 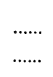 & $\ldots . .$. & $\ldots \ldots$. & 66 & $\begin{array}{r}186 \\
17\end{array}$ & $\begin{array}{r}345 \\
34\end{array}$ \\
\hline
\end{tabular}

Untreated control: 3 .

w.p. - wettable powder.

g. - granule.

Differences between treatments were so large that no formal statistical analysis has been considered necessary. The value 3 for the untreated control is almost entirely due to 15 larvae found on the extreme edge of one plot, probably the result of spray drift.

\section{Trial 2}

This trial included both diazinon wettable powder and GS.13005 wettable powder. Both materials exhibited a knockdown effect, and GS.13005 was superior to equivalent rates of diazinon.

\section{Trial 3}

The full range of materials considered in this paper were included in this trial. In the case of diazinon wettable powder, the formulation was evaluated both with and without the addition of a wetting agent.

TABLE 2: MEAN COUNTS OF AFFECTED LARVAE PER PLOT (TRIAL 3)

\begin{tabular}{|c|c|c|c|c|c|c|c|}
\hline \multirow[b]{2}{*}{ Treatment } & & \multicolumn{6}{|c|}{ Rate (lb) } \\
\hline & & 0.25 & 0.5 & 0.75 & 1.0 & 1.5 & 2.0 \\
\hline Diazinon w.p. & $\cdots \cdots$ & 一 & 6 & - & 66 & 83 & - \\
\hline Diazinon w.p. +WA & $\ldots \ldots$ & 一 & 13 & - & 29 & 92 & 一 \\
\hline Diazinon g. ....... ....... & ....... & - & 10 & - & 5 & 20 & - \\
\hline GS.13005 w.p. & ....... & 4 & 10 & 33 & - & - & - \\
\hline GS.13005 g. & $\ldots \ldots$ & 5 & 7 & - & 9 & - & - \\
\hline Trichlorphon s.p. ....... & $\ldots \ldots$ & - & - & - & 33 & - & - \\
\hline DDT granule ............. & $\ldots \ldots$ & - & - & - & - & - & 0 \\
\hline
\end{tabular}

Untreated control : 0 .

s.p. - soluble powder.

WA - wetting agent. 


\section{Pasture Response}

Pasture response was assessed on an arbitrary scale of either 1 to 5 or 1 to 10 , with 1 representing the poorest plot and either 5 or 10 the best plot.

\section{Trial 1}

Table 3 shows an assessment of Trial 1, 22 days after treatments were applied. Data are unsuitable for analysis but inspection would indicate that treatments have led to a visible growth response.

TABLE 3: ASSESSMENT OF GROWTH RESPONSE (TRIAL 1)

\begin{tabular}{|c|c|c|c|c|c|c|c|c|c|}
\hline \multirow[b]{2}{*}{ Treatment } & & & & & & & \multicolumn{3}{|c|}{ Rate (lb) } \\
\hline & & & & & & & 0.5 & 1.0 & 2.0 \\
\hline $\begin{array}{l}\text { Diazinon w.p. ....... } \\
\text { Diazinon g. }\end{array}$ & $\ldots$ & $\begin{array}{l}\ldots \ldots . . \\
\ldots \ldots . .\end{array}$ & $\begin{array}{l}\ldots \ldots . . \\
\ldots \ldots . .\end{array}$ & $\begin{array}{l}\ldots \ldots . . \\
\ldots \ldots . .\end{array}$ & …. & $\ldots \ldots$. & 2.7 & $\begin{array}{l}3.0 \\
3.0\end{array}$ & $\begin{array}{l}3.3 \\
3.6\end{array}$ \\
\hline
\end{tabular}

Untreated control: 1.8

1 - poorest; 5-best.

\section{Trial 2}

Two assessments were made by one observer and mean scores are shown in Table 4. This trial was laid late in the season when larvae were fully grown and major pasture damage had been caused before treatments were applied.

TABLE 4: ASSESSMENT OF GROWTH RESPONSE (TRIAL 2)

\begin{tabular}{lcccccccc}
\hline & & \multicolumn{3}{c}{ First Assessment* } & \multicolumn{3}{c}{ Second Assessment } \\
Treatment & & Rate & 0.5 & 1.0 & 2.0 & 0.5 & 1.0 & 2.0 \\
\hline Diazinon w.p. & $\ldots \ldots$. & $\ldots \ldots$. & 2.7 & 4.3 & 3.7 & 3.3 & 3.0 & 4.3 \\
Diazinon g. ..... & $\ldots . .$. & $\ldots .$. & - & 3.3 & 3.0 & - & 3.7 & 4.3 \\
GS.13005 w.p. & $\ldots . .$. & $\ldots . .$. & 3.0 & 4.7 & 5.0 & 3.0 & 4.3 & 4.7 \\
\hline
\end{tabular}

Untreated control: 1.4. Untreated control at 2nd assessment: 1.8 1 - poorest; 5-best.

* A significant difference of 1.3 units is applicable to comparisons within the first set of observations and this would be approximately the same for the second observations.

\section{Trial 3}

Pasture response was rated three and six weeks after treatment. Table 5 shows the treatments tabulated in descending order of performance as at the second observation.

For the second assessment, significant differences for comparison within Table 5 are 1.8 for the $5 \%$ level and 2.4 for the $1 \%$ level of significance. The first assessment was made by two observers and the second assessment by three observers. 
TABLE 5: ASSESSMENT OF GROWTH RESPONSE (TRIAL 3)

\begin{tabular}{|c|c|c|c|c|c|c|c|}
\hline Treatment & & & & & $\begin{array}{l}\text { Rate } \\
(l b)\end{array}$ & $\begin{array}{l}\text { First } \\
\text { Assessment }\end{array}$ & $\begin{array}{c}\text { Second } \\
\text { Assessment }\end{array}$ \\
\hline $\begin{array}{l}\text { 1. Diazinon w.p.* } \\
\text { 2. Diazinon g. ..... } \\
\text { 3. GS.13005 w.p. } \\
\text { 4. GS.13005 w.p. } \\
\text { 5. Diazinon w.p.* }\end{array}$ & $\begin{array}{l}\cdots \cdots . \\
\cdots \cdots . \\
\cdots \cdots . \\
\cdots \cdots \\
\cdots \cdots\end{array}$ & $\begin{array}{l}\cdots \cdots . \\
\cdots \cdots . \\
\cdots \cdots . \\
\cdots \cdots \\
\cdots \cdots\end{array}$ & $\begin{array}{l}\cdots \cdots . \\
\cdots \cdots . \\
\cdots \cdots . \\
\cdots \cdots . \\
\cdots \cdots\end{array}$ & $\begin{array}{l}\cdots \cdots \\
\ldots \ldots . . \\
\cdots \cdots . \\
\cdots \cdots \\
\cdots \cdots\end{array}$ & $\begin{array}{l}1.0 \\
1.5 \\
0.5 \\
0.75 \\
1.5\end{array}$ & $\begin{array}{l}8.8 \\
8.8 \\
8.2 \\
6.8 \\
8.2\end{array}$ & $\begin{array}{l}8.9 \\
8.8 \\
8.3 \\
8.3 \\
8.0\end{array}$ \\
\hline $\begin{array}{l}\text { 6. Diazinon w.p. } \\
\text { 7. GS.13005 g. ...... } \\
\text { 8. GS.13005 w.p. } \\
\text { 9. Diazinon w.p. } \\
\text { 10. Diazinon w.p. } \\
\text { 11. Diazinon g. ...... }\end{array}$ & 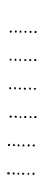 & 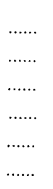 & 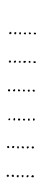 & $\begin{array}{l}\ldots \ldots . \\
\ldots \ldots . \\
\ldots \ldots . \\
\ldots \ldots . \\
\ldots \ldots . \\
\ldots \ldots . \\
\ldots \ldots\end{array}$ & $\begin{array}{l}1.5 \\
1.0 \\
0.25 \\
0.5 \\
1.0 \\
1.0\end{array}$ & $\begin{array}{l}6.5 \\
8.2 \\
6.8 \\
6.2 \\
5.5 \\
7.0\end{array}$ & $\begin{array}{l}7.8 \\
7.7 \\
7.5 \\
7.1 \\
7.1 \\
7.0\end{array}$ \\
\hline $\begin{array}{l}\text { 12. Trichlorphon s.p. } \\
\text { 13. Diazinon w.p.* } \\
\text { 14. Diazinon g. ..... } \\
\text { 15. DDT granules } \\
\text { 16. GS.13005 g. ..... }\end{array}$ & $\begin{array}{l}\cdots \cdots \\
\cdots \cdots . . \\
\cdots \cdots \\
\cdots \cdots . . \\
\cdots \cdots\end{array}$ & $\begin{array}{l}\ldots \ldots . \\
\ldots \ldots . \\
\ldots \ldots . . \\
\ldots \ldots . . \\
\ldots \ldots . .\end{array}$ & $\begin{array}{l}\ldots \ldots . \\
\ldots \ldots . \\
\ldots \ldots . \\
\ldots \ldots . \\
\ldots \ldots . .\end{array}$ & $\begin{array}{l}\ldots \ldots . \\
\ldots \ldots . \\
\ldots \ldots . \\
\ldots \ldots . \\
\ldots \ldots . .\end{array}$ & $\begin{array}{l}1.0 \\
0.5 \\
0.5 \\
2.0 \\
0.5\end{array}$ & $\begin{array}{l}6.3 \\
5.0 \\
4.6 \\
6.8 \\
6.5\end{array}$ & $\begin{array}{l}6.9 \\
6.7 \\
6.2 \\
6.1 \\
6.0\end{array}$ \\
\hline $\begin{array}{l}\text { 17. Untreated control } \\
\text { 18. GS.13005 g. ...... }\end{array}$ & $\ldots \ldots$. & $\begin{array}{l}\ldots \ldots . \\
\ldots \ldots .\end{array}$ & $\ldots \ldots$ & $\ldots \ldots$ & $\overline{0.25}$ & $\begin{array}{l}4.1 \\
4.2\end{array}$ & $\begin{array}{l}4.0 \\
3.9\end{array}$ \\
\hline
\end{tabular}

* Indicates addition of surface-acting agent.

1 - poorest; 10 - best.

\section{Reduction in Larval Population}

\section{Trial 1}

Three spade square samples per plot were taken to determine residual popilations of larvae after treatment. Samples were taken 9 and 22 days after treatment and results are shown in Table 6. Later sampling was not possible as the trial area was
ploughed.

When plots were sampled 22 days after treatment, larvae from the treated plots were smaller and less active than those in the untreated control plots. Dead larvae were also found in the treated areas and it can be assumed that deaths had occurred only shortly before sampling since decomposition is very rapid.

\section{RESIDUE OF DiaZinon in LaRvaE}

Larvae collected from the ground surface in Trial 1 were assayed for diazinon content by the sulphide method. Larvae were macerated with solvent and analysis represents total unmetabolized diazinon both external and internal. Mean diazinon content was found to be $1.8 \mathrm{ppm}$ 
'AABLE 6: MEAN COUNTS OF SURVIVING LARVAE (TRIAL 1)

\begin{tabular}{|c|c|c|c|c|c|}
\hline \multirow[b]{2}{*}{ Treatment } & & \multicolumn{4}{|c|}{ FIRST ASSESSMENT } \\
\hline & & Rate & 0.5 & 1.0 & 2.0 \\
\hline $\begin{array}{l}\text { Diazinon w.p. } \\
\text { Diazinon g. }\end{array}$ & $\begin{array}{c}\ldots \ldots . . \\
\ldots \ldots . .\end{array}$ & $\ldots \ldots$ & $9.0 \mathrm{bcAB}$ & $\begin{array}{l}12.0 \mathrm{abAB} \\
11.6 \mathrm{abAB}\end{array}$ & $\begin{array}{c}5.0 \mathrm{cB} \\
11.0 \mathrm{abAB}\end{array}$ \\
\hline Untreated control & $\ldots \ldots .$. & $\ldots \ldots .$. & & $14.5 \mathrm{aA}$ & \\
\hline & & & & ND ASSESSN & \\
\hline Treatment & & Rate & 0.5 & 1.0 & 2.0 \\
\hline $\begin{array}{l}\text { Diazinon w.p. } \\
\text { Diazinon g. }\end{array}$ & $\ldots \ldots$. & $\ldots \ldots$. & $10.0 \mathrm{abAB}$ & $\begin{array}{l}6.3 \mathrm{bcBC} \\
6.0 \mathrm{cBC}\end{array}$ & $\begin{array}{l}2.3 \mathrm{dC} \\
7.1 \mathrm{bcBC}\end{array}$ \\
\hline Untreated control & $\ldots \ldots$ & $\ldots \ldots$. & & $12.7 \mathrm{aA}$ & \\
\hline
\end{tabular}

\section{DISCUSSION}

The collection of larvae from the soil surface following treatment has shown that diazinon, GS.13005, and trichlorphon applied as sprays cause rapid knockdown. Formulation is an important factor sprays cause rapid knockdown. Formulation in determining the magnitude of thisuced high surface counts of that diazinon wettable pow with diazinon granular formulations. Comparisons between GS.13005 wettable powder and granules show Comparisons between GS.1300 affected larvae tend to increase with a similar pattern. Counts of affected lawn of fully grown larvae application rate of toxicant. Knockdown of fully grown larva was obtained with both diazinon and GS.13005 wettable powders.

In Trial 3 it was found that DDT granules did not exhibit any knockdown effect. It has previously been reported (Taylor, 1964) that granular DDT is inferior to spray or dust formulations and

It is not suggested that knockdown effect should be considered as an absolute indication of insecticide performance. It is, however, as an absolute indication o insecticides are of potential value for an indication that som initial knockdown significantly affects overall population, then such assessments have signifcantly affects a definite applied value. Insecticide improvement of pasture quantity or quality.

In the trials, diazinon and GS.13005 formulations led to a pasture

In the trials, diazinon and of treatment as indicated by Tables response within three weeks of tations of diazinon have not shown the same knockdown effect as the wettable powder formulations but pasture response has been comparable.

Whilst observations in Trial 2 show that diazinon and GS.13005 Whilst observations in Trial 2 show the grown larvae, the resulting wettable powder was small compared with earlier treatments. pasture response was of Trial 2, the treatment differences were At the second inspection owing to the onset of active spring growth. not as marked as earlier owing treatments should be applied early in the season.

Observations in Trial 1 indicate that diazinon wettable powder and granules will significantly reduce overall larval populations 
and this supports the findings of Helson et at. (1964). The assay of affected larvae showed diazinon content to be very low.

Recent overseas work with small birds has studied the effect of including diazinon in the diet over a seven-day period. Feeding levels of $40 \mathrm{ppm}$ did not result in any deaths in a group of ten birds and a feeding level of $80 \mathrm{ppm}$ resulted in the death of one bird cilt of ten (Belibs, 1965). The use of diazinon for control of subterranean grass caterpillar control is unlikely to cause bird mortality.

\section{REFERENCES}

Belibs, R. P., 1965 : Diazinon, Safety Evaluation on Fish and Wildlife. Report to Geigy Agricultural Chemicals, U.S.A.

Entomology Division, D.S.I.R., 1961: Annual Report.

Helson, G. A. H.; Meeklah, W. F. A.; Darwin, R. K.; Robertson, T. G., 1964: Proc. 17th N.Z. Weed \& Pest Control Conf.: 165-7.

Taylor, R. L., 1964 : Proc. 17th N.Z. Weed \& Pest Control Conf.: 145-8. 